\title{
От главного редактора
}

Пространственная Экономика

2020. Том 16. № 4. С. 7-22

JEL: R10, I38, H50

https://dx.doi.org/10.14530/se.2020.4.007-022

УДК $332+338$

\section{Экономика панgемии: gальневосточный acпekт}

\author{
П.А. Минакир
}

Минакир Павел Александрович

академик РАН, доктор экономических наук, профессор

научный руководитель

Институт экономических исследований ДВО РАН, ул. Тихоокеанская, 153, Хабаровск, 680042, Российская Федерация

E-mail: minakir@ecrin.ru

ORCID: 0000-0002-5451-5662

Аннотащия. В статье продолжен анализ общенациональных и международных аспектов оценки экономических последствий пандемии новой коронавирусной инфекции. Анализируются финансово-экономические результаты за 11 месяцев 2020 г. с выделением особенностей экономической ситуации, складывающейся в Дальневосточном федеральном округе. Рассматривается общее различие пандемической ситуации в целом по России и на Дальнем Востоке, отмечается, что в макрорегионе состояние баланса нагрузки и резервов для медико-социальной системы более напряженное, чем в целом по РФ. Анализируются оценки экономических потерь, связанных с пандемией, по основным структурным сегментам дальневосточной экономики (промышленность, бюджеты, внешняя торговля, рынок труда, строительство). Рассматриваются варианты отклонения от нормативных значений программных индикаторов. Определены наиболее существенные направления воздействия пандемии для экономики Дальнего Востока: уменьшение выпуска и доходов из-за остановки деятельности или даже ухода с рынка предприятий; снижение размеров производства из-за падения спроса; сокращение стоимости экспорта изза закрытия границ, снижения спроса на зарубежных рынках и сокращения добычи ресурсов; повышение цен из-за сокращения размеров импорта; увеличение дефицита рабочей силы из-за закрытия границ; рост расходов и сокращение налоговых доходов региональных бюджетов. Выделены три больших сектора экономики ДФО по степени потерь от пандемии: самый большой сектор (почти $2 / 3$ всей экономики) образуют виды экономической деятельности, потерявшие и до сих пор теряющие доходы и снизившие оборот в результате снижения спроса; 13\% экономики составили те производства и сектора, которые несут и несли потери и даже ушли с рынка в результате весеннего локдауна и тех ограничений, которые начинают вводиться, в том числе и на территории Дальнего Востока; примерно 20\% экономики оказались в выигрыше или остались нейтральными (частично медицина, частично образование, фармацевтическая промышленность, электроэнергетика, нефтеперерабатывающая промышленность, связь).

\footnotetext{
(C) Минакир П.А., 2020
} 
Ключевые слова: пандемия, финансовые результаты, стагнация, виды экономической деятельности, Дальний Восток

Для ичттирования: Минакир П.А. Экономика пандемии: дальневосточный аспект // Пространственная экономика. 2020. Т. 16. № 4. С. 7-22. https://dx.doi.org/10.14530/ se.2020.4.007-022

\section{The Economy of the Pandemic: A Far Eastern Russian Aspect}

\section{P.A. Minakir}

Pavel Aleksandrovich Minakir

Academician RAS, Doctor of Economics, Professor

Research Supervisor

Economic Research Institute FEB RAS, 153 Tikhookeanskaya St., Khabarovsk, 680042, Russian Federation

E-mail: minakir@ecrin.ru

ORCID: 0000-0002-5451-5662

Abstract. The article presents continuation of analysis of national and international aspects in assessment of economic after-effects of a new corona virus pandemic. It analyzes the finance and economy performance for 11 months of 2020 with a stress on specific economic situation in the Far Eastern Federal Okrug (FEFO, district). It regards a basic difference in the pandemic situation between overall Russia and its Far East. The author notes that the macro region demonstrates a tighter balance between the load and the available reserves in primary health care (medical and social) as compared to Russia overall. Estimated and assessed are economic losses related to the pandemic in the key structural segments of the Far Eastern Russia economy (industry, budgets, foreign trade, labour market, construction). Variance of program indicators is considered. The following most meaningful lines of the pandemic influence on the Far East economy have been identified: curtailing output and revenue from a stop-over or even exit from the market; scalingdown production after a fall in demand; decreasing value of exports with closing borders; falling foreign market demand and falling mineral resource extraction; an upswing rise in prices caused by shrinking imports; a growing shortage of manpower from closed borders; growing expenses and decreasing tax revenues for regional budgets. Three larger FEFO economy sectors are described as to their losses from the pandemic: the bigger sector (almost $2 / 3$ of the entire economy) is formed by the types of economic activity that have lost and are still losing revenue and those that have reduced turnover following the shrinking demand; $13 \%$ of the economy have suffered from a spring lock-down; approximately $20 \%$ of the economy are either winners or those neutral to the situation.

Key words: pandemic, finance performance, stagnation, types of economic activity, Far East Russia

For citation: Minakir P.A. The Economy of the Pandemic: A Far Eastern Russian Aspect. Prostranstvennaya Ekonomika = Spatial Economics, 2020, vol. 16, no. 4, pp. 7-22. https:// dx.doi.org/10.14530/se.2020.4.007-022 (In Russian). 
Объявленная в январе 2020 г. Всемирной организацией здравоохранения пандемия COVID-19 «добралась», как известно, до России с некоторой задержкой. Быстрое блокирование границы с КНР помогло практически избежать первых заражений, которые в январе - феврале накрыли Китай и перекинулись на Западную Европу и США. Формальное закрытие границ, которые на самом деле оставались проницаемыми для передвижения людей, произошло только в конце марта, когда через Западную Европу вирус уже проник в Россию и начал быстро распространяться, формируя отчетливую волну роста заражений (рuc. 1). В Азии и Европе эта волна сформировалась значительно раньше, там высокий уровень заражений регистрировался с января - февраля.

Для Дальнего Востока общая динамика нагрузки на систему здравоохранения и, соответственно, объективного нарастания экономических шоков, вызванных попытками ослабить эту нагрузку, имеет специфику. В отличие от национальной динамики заражений, в которой отчетливо выделяются первая (апрель - июнь) и вторая (начиная с сентября) волны, на Дальнем Востоке первая волна (апрель - август) была относительно пологой, а вторая началась только с октября (рис. 2). На пике первой волны в целом по России интенсивность заражений составляла 6,1 чел. на 100 тыс. чел. населения, а для Дальнего Востока - 5,5.

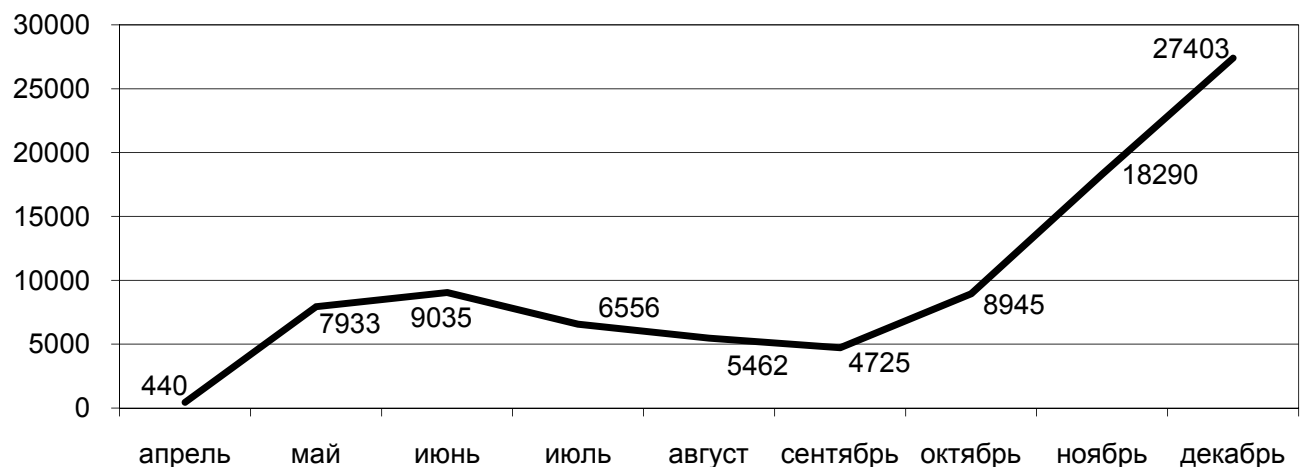

Puc. 1. Динамика заражений в РФ (на начало месяца)

Fig. 1. Virus infection in RF (first of the month)

Источник: Карта..., 2020.

Ситуация изменилась в ходе прохождения второй волны. В начале декабря уровень заражений в расчете на 10 тыс. чел. населения (на дату) составил более 20 чел. на Дальнем Востоке против 18,5 чел. в среднем по России. Если в ходе первой волны на Дальнем Востоке общая ситуация была под контролем, то к концу года положение ухудшилось. 


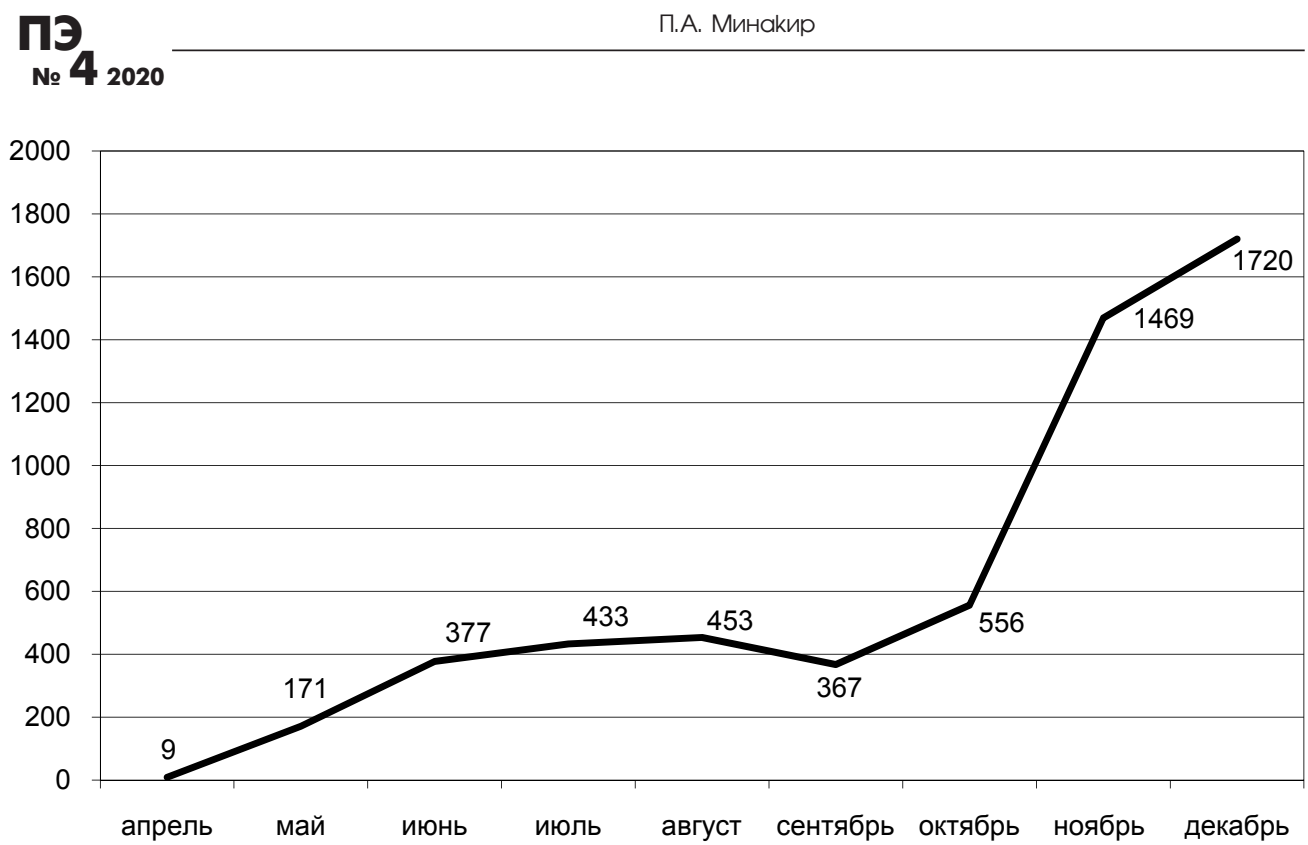

Puc. 2. Динамика заражений на Дальнем Востоке (на начало месяца)

Fig. 2. Virus infection in Far East Russia (first of the month)

Источник: Карта..., 2020.

И для всего федерального округа, и для отдельных субъектов РФ, входящих в его состав, при, в общем-то, благоприятном положении с точки зрения смертности от новой коронавирусной инфекции нагрузка на систему здравоохранения, превышает, и в ряде случаев очень значительно, те индикаторы, которые регистрируются в целом по России (табл. 1).

Для отдельных дальневосточных регионов положение выглядит крайне тревожным с точки зрения количества так называемых активных случаев, требующих медицинского контроля и задействования кадровых, финансовых и материально-технических ресурсов. В ходе многолетних экспериментов по псевдооптимизации здравоохранения мобилизационные возможности здравоохранения были существенно подорваны. В наибольшей степени это коснулось не просто регионов, но тех из них, которые характеризуются низкой плотностью населения и дефицитностью собственных бюджетов. Практически все дальневосточные регионы находятся в этой категории.

В то же время угроза исчерпания существующих резервов чревата полной потерей контроля над социальной ситуацией, что вполне способно спровоцировать политический коллапс. Выбор в самом начале пандемии действительно был неприятен, хотя и сейчас он остается таким же. С одной стороны, без жесткого карантина есть опасность потерять контроль над и без того ослабленной в результате всевозможных «оптимизаций» (свойствен- 
ных далеко не одной только России) системой здравоохранения и получить взлет смертности. С другой стороны, лекарство (карантин) может оказаться смертельным для экономики. Экономический коллапс - кратчайший путь к разрушению экономической и социальной инфраструктур, под завалами которых погибнуть может и спасаемая карантином система здравоохранения. А если это произойдет, то нового удара пандемии (то, что сейчас наблюдается вторая волна, не означает, что не может быть и последующих) сдержать уже будет невозможно (Auzan, 2020, p. 8). В России попытки найти оптимальную комбинацию решений предпринимаются с апреля 2020 г.

Эпидемиологическая ситуация к началу декабря 2020 г.

Таблица 1

Far East Russia epidemic situation by early December 2020

Table 1

\begin{tabular}{l|c|c|c}
\hline \multicolumn{1}{c|}{ Регион } & $\begin{array}{c}\text { Число } \\
\text { активных } \\
\text { случаев* }\end{array}$ & $\begin{array}{c}\text { Число активных } \\
\text { случаев на 100 тыс. чел. } \\
\text { населения }\end{array}$ & $\begin{array}{c}\text { Доля летальных } \\
\text { исходов в общем } \\
\text { числе заражений, \% }\end{array}$ \\
\hline Республика Бурятия & 2159 & 219,1 & 1,7 \\
\hline Республика Саха (Якутия) & 6068 & 627,5 & 1,2 \\
\hline Забайкальский край & 3633 & 340,9 & 1,4 \\
\hline Камчатский край & 2253 & 716,8 & 1,1 \\
\hline Приморский край & 4094 & 215,2 & 0,8 \\
\hline Хабаровский край & 6306 & 477,2 & 0,8 \\
\hline Амурская область & 1988 & 250,6 & 0,05 \\
\hline Магаданская область & 1178 & 828,6 & 1,6 \\
\hline Сахалинская область & 2928 & 598,1 & 1,1 \\
\hline Еврейская автономная область & 1107 & 692,3 & 1,1 \\
\hline Чукотский автономный округ & 35 & 70,4 & 1,7 \\
\hline ДФО & 31749 & 387,5 & \\
\hline РФ & 436010 & 307,0 & \\
\hline
\end{tabular}

Примечание. * Разница между общим количеством заражений, количеством выздоровевших и ушедших из жизни людей.

Источник: Карта..., 2020.

Правительство РФ выделило целый список направлений деятельности отраслей и видов бизнеса, наиболее подверженных негативным шокам, генерируемым этой инфекцией и принимаемыми для борьбы с ней ограничительными мерами. Этот список изначально включал девять секторов, полагая, что именно они больше остальных нуждаются в государственной помощи:

- авиаперевозки, аэропорты, автоперевозки;

- культура, организация досуга и развлечений; 
- физкультурно-оздоровительная деятельность и спорт;

- деятельность туристических агентств и прочих организаций, предоставляющих услуги в сфере туризма;

- гостиничный бизнес;

- общественное питание;

- организации дополнительного образования, негосударственные образовательные учреждения;

- организация конференций и выставок;

- предоставление бытовых услуг населению (ремонт, стирка, химчистка, услуги парикмахерских и салонов красоты) (Курюкин, 2020).

Почему-то в список этих видов деятельности не попала, например, сфера розничной торговли непродовольственными товарами, которую, конечно, следует выделить. Но даже без торговли список производит впечатление с точки зрения объема ресурсов, которые следовало привлечь или которые ожидались для привлечения с целью компенсации ущерба в экономике. Однако кроме «прямых» пострадавших существует еще один, гораздо более длинный список видимых и невидимых потерь, к которым относятся потери доходов домашних хозяйств и бизнеса в связи с принудительной и «естественной» (в результате сокращения совокупного спроса) остановкой роста вплоть до его ухода в отрицательную область на рынках труда, благ и услуг. Эти эффекты не являются, конечно, чисто российскими, они проявились в глобальном аспекте. Спад конечного личного потребления спровоцировал по цепочке отраслей сокращение производства, потребления, экспорта, инвестиций, начиная от Китая и далее в развитых странах. Наиболее уязвимые сектора экономики только иллюстрируют проблему, которая, впрочем, быстро проявилась как масштабная глобальная рецессия в форме падения ВВП, нарастания финансовых и долговых проблем бизнеса (Grigoryev, 2020).

В российском случае пандемия, впрочем, далеко не сразу была идентифицирована как основная угроза 2020 г. Начало первой волны пандемии в России было с финансово-экономической точки зрения заслонено в значительной степени событиями на нефтяном и валютном рынках.

В начале апреля более чем в 3 раза по сравнению с началом года рухнули мировые цены на нефть (рис. 3). Обрушение произошло почти одновременно с вводом ограничений на деятельность целого ряда отраслей, что поставило на повестку дня вопрос о крупных финансовых вливаниях из федерального бюджета на борьбу с последствиями пандемии. Учитывая, что без малого 40\% доходов российского бюджета формируется за счет нефтяных доходов, это стало сильным ударом по финансовой системе. 


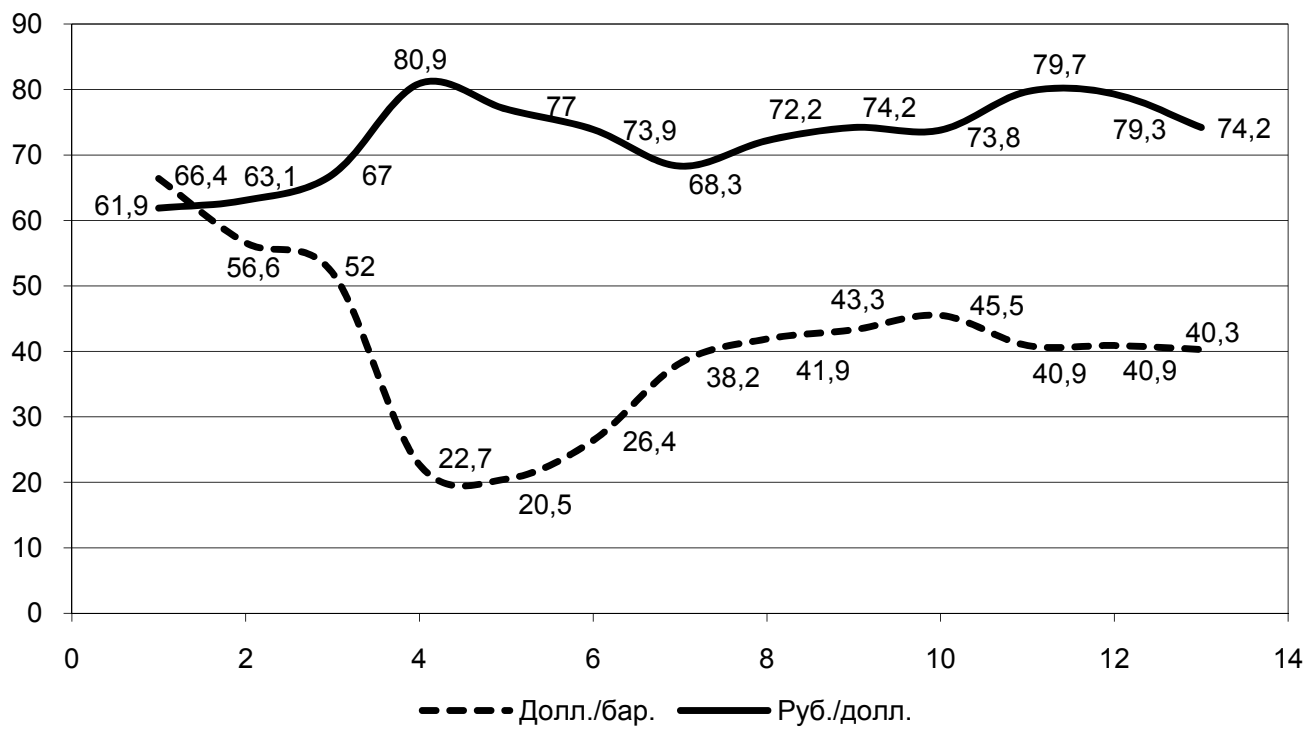

Puc. 3. Мировые цены на нефть (Brent), долл. США за баррель Fig. 3. Oil world prices (Brent), USD per barrel

Источники: Нефть..., 2020; Курс..., 2020.

Вторым обстоятельством, на первый взгляд непосредственно связанным с обрушением нефтяных цен, стали потрясения на валютном рынке, девальвация рубля, курс которого к доллару практически одномоментно обрушился почти на $30 \%$ (см. puc. 3). Девальвация сыграла роль финансового демпфера и до некоторой степени компенсировала сокращение доходов, которые должны были поступать в федеральный бюджет и, соответственно, использоваться для финансирования антикоронавирусных мероприятий. Хотя нефтяные цены к середине лета в некоторой степени восстановились, не достигнув докризисного уровня, но все же увеличившись более чем в 2 раза, курс рубля остался практически на уровнях апреля, что означает примерно 25-процентную девальвацию. Это сыграло в пользу доходов бюджета и до некоторой степени объясняет макроэкономическое «спокойствие» федеральных экономических и финансовых властей.

По информации правительства РФ, общие финансовые затраты, связанные с пандемией, в целом по стране составили 4,8\% ВВП (более 5 трлн руб.). Кроме девальвации рубля важным источником финансирования затрат, связанных с пандемией, стал прирост государственного долга. Чистый прирост государственного долга, направленный на финансирование «ковидных» затрат, составил более 3 трлн руб., или 60\% общей суммы затрат. В совокупности это обеспечило удивительный на первый взгляд результат - прирост 
в 2020 г. Фонда национального благосостояния. В опубликованной на эту тему статье автора был оценен прирост государственного долга для финансирования мероприятий по компенсации потерь от пандемии в 4-4,5 трлн руб. при практически полном исчерпании Фонда национального благосостояния (Минакир, 2020, с. 15). Фактически даже после выплаты из этого фонда 2,4 трлн руб. за пакет акций Сбербанка удалось увеличить сумму Фонда национального благосостояния. Этот «фокус» удивителен только на первый взгляд, если вспомнить, что Фонд национального благосостояния номинирован в долларах и евро, рублевый эквивалент которых увеличился благодаря конвертации валютной корзины Фонда национального благосостояния практически на пике девальвации рубля и дальнейшему приросту доходов фонда при растущих ценах на нефть и высокой стоимости доллара / евро в рублях. Таким образом, уже к концу октября величина Фонда национального благосостояния составила 13,7 трлн руб. (Статистика..., 2020).

Финансовые результаты в России с точки зрения бухгалтерского баланса должны расцениваться как положительные. Такое «финансовое чудо», конечно, обеспечено не только бесцеремонным манипулированием курсом национальной валюты. За эти манипуляции, которые фактически означают просто перекладывание финансового бремени по компенсации затрат на преодоление пандемических шоков на население и бизнес, последним еще предстоит расплачиваться в ближайшей перспективе в форме сокращения ликвидных ресурсов для накопления капитала на величину прироста процентных платежей по государственному долгу и снижения реального уровня доходов домашних хозяйств и предпринимательского сектора.

Но самое непосредственное отношение к «финансовому чуду» имеет суперэкономное расходование средств на поддержку экономики и населения (около 65 млрд долл. США при совокупных затратах в США, Великобритании, Германии, Италии, Японии и КНР более 5 трлн долл.) (Минакир, 2020, c. 13). Сравнение номинальных затрат мало что объясняет, но содержание собственно характера поддержки и, соответственно, доли бюджетных интервенций на ее осуществление объясняет гораздо больше.

Даже краткий обзор основных мер государственной поддержки показывает их «немонетарный характер» (табл. 2).

Таким образом, применяется целый комплекс мер, но в основном не финансового характера, а относящихся к административному, налоговому, кредитному маневрам. Это касается и социальной поддержки, которая хотя и оказывалась в финансовых формах, но выплаты были довольно скромными. Конечно, для российской экономики финансовая нагрузка может считаться высокой соотносительно с возможностями бюджета. Все-таки 65 млрд долл. сопоставимы с годовым оборонным бюджетом страны. Но следует 
еще раз подчеркнуть, что чисто финансовый результат, оставаясь в рамках официальных оценок затрат на пандемию, оказался удивительным образом положительным для государственных финансов: при затратах в 5 трлн руб. прирост Фонда национального благосостояния составил 5,9 трлн руб. Государственные финансы останутся в «плюсе», даже если учесть ожидаемую потерю примерно в 0,7 трлн руб. налоговых доходов бюджета в связи с официально продекларированным ожиданием уменьшения стоимости ВВП в этом году на 4-4,5\%.

Меры государственной поддержки в РФ

Таблица 2

в связи с пандемией в 2020 г.

Table 2

RF state support measures in connection with pandemic in 2020

\begin{tabular}{c|l}
\hline \multicolumn{1}{c|}{$\begin{array}{c}\text { Сфера } \\
\text { подержки }\end{array}$} & \multicolumn{1}{|c}{ Формы поддержки } \\
\hline Налоговая & $\begin{array}{l}\text { Поддержка системообразующих компаний (субсидии для возме- } \\
\text { щения затрат, отсрочки по уплате налогов, гарантии по кредитам } \\
\text { или облигационным займам, привлекаемым системообразующи- } \\
\text { ми организациями на решение неотложных задач по обеспече- } \\
\text { нию устойчивости экономического развития, суммарный объем } \\
\text { кредита, выданный группе компаний, от } 3 \text { до } 5 \text { млрд руб. по став- } \\
\text { ке 5\% годовых, период субсидирования ставки - } 1 \text { год) } \\
\text { Отсрочка или рассрочка по налогам, авансовым платежам, стра- } \\
\text { ховым взносам в 2020 г., кроме НДС, НДПИ, акцизов и налога на } \\
\text { дополнительный доход от добычи углеводородного сырья } \\
\text { Продление срока уплаты налогов для МСП и НКО } \\
\text { Продление срока предоставления налоговой отчетности на } 3 \text { ме- } \\
\text { сяца } \\
\text { Снижение совокупного тарифа страховых взносов с } 30 \text { до 15\% } \\
\text { для части зарплат, превышающей в течение месяца МРОТ } \\
\text { (12 130 руб.) } \\
\text { Учет медицинских закупок при исчислении налога на прибыль } \\
\text { Уменьшение страховых взносов для ИП в наиболее пострадав- } \\
\text { ших отраслях (на один МРОТ) } \\
\text { Освобождение МСП и НКО от налогов, сборов, страховых взно- } \\
\text { сов за ІІ квартал 2020 г. } \\
\text { Изменение срока предоставления налоговых документов } \\
\text { Освобождение от налогов субсидий для МСП } \\
\text { Освобождение от НДФЛ выплат медикам } \\
\text { Освобождение от НДФЛ субсидий ИП } \\
\text { Приостановка взысканий налоговых задолженностей }\end{array}$ \\
\hline
\end{tabular}




\begin{tabular}{|c|c|}
\hline 1 & 2 \\
\hline Социальная & $\begin{array}{l}\text { Назначение пособий и выплат без предоставления справок } \\
\text { Выплаты на детей от } 3 \text { до } 7 \text { лет в размере } 50 \% \text { регионального } \\
\text { прожиточного минимума, а на детей от } 3 \text { до } 16 \text { лет единовремен- } \\
\text { ная выплата в } 10 \text { тыс. руб., на детей до } 3 \text { лет по } 5 \text { тыс. руб. во } \\
\text { II квартале } \\
\text { Выплата пособий по безработице в размере } 12130 \text { руб. плюс } \\
3 \text { тыс. руб. на каждого ребенка } \\
\text { Доплата медработникам к регулярной к заработной плате } \\
\text { Выплаты волонтерам (12 } 130 \text { руб.) } \\
\text { Увеличение размеров пособия по уходу за ребенком в } 2 \text { раза } \\
\text { Продление срока действия документов для иностранцев на тер- } \\
\text { ритории РФ }\end{array}$ \\
\hline Финансовая & $\begin{array}{l}238 \text { млн руб. на поддержку зоопарков } \\
\text { Упрощенный доступ к господдержке для электронной промыш- } \\
\text { ленности } \\
\text { Компенсация затрат для МСП и НКО на профилактику корона- } \\
\text { вируса } \\
10,9 \text { млрд руб. - субсидии аэропортам } \\
\text { Возврат самозанятым налогов за } 2019 \text { г. } \\
\text { Кредиты на поддержку занятости под 2\% } \\
\text { Каникулы до } 6 \text { месяцев на уплату процентов по ипотеке и потре- } \\
\text { бительскому кредиту, МСП и пострадавших отраслей } \\
\text { Льготное кредитование по } 8,5 \% \text { и } 5 \% \text { для сельскохозяйственных } \\
\text { предприятий } \\
\text { Субсидирование кредитов на оборотные средства } \\
\text { Ипотека в новостройках под 6\% } \\
12 \text { млрд руб. для выдачи микрокредитов } \\
\text { Льготные кредиты для производства медицинских товаров } \\
\text { Защита от банкротства на } 6 \text { месяцев для пострадавших } \\
\text { Отмена санкций по госконтрактам } \\
20 \text { млрд руб. на поддержку автопрома } \\
\text { Отсрочка погашения и реструктуризация аграрных кредитов } \\
450 \text { млн руб. для сертификации экспортной продукции } \\
\text { Предоставление субсидий банкам для кредитования }\end{array}$ \\
\hline
\end{tabular}

Для экономики Дальнего Востока существенны следующие направления воздействия пандемии:

- уменьшение выпуска и доходов из-за остановки деятельности или даже ухода с рынка предприятий; 
- снижение размеров производства из-за падения спроса;

- сокращение стоимости экспорта из-за закрытия границ, снижения спроса на зарубежных рынках и сокращения добычи ресурсов;

- повышение цен из-за сокращения размеров импорта;

- увеличение дефицита рабочей силы из-за закрытия границ;

- рост расходов и сокращение налоговых доходов региональных бюджетов.

Перечень наиболее пострадавших от воздействия пандемических шоков в регионе отраслей и видов экономической деятельности имеет важные отличия от общероссийского перечня (транспорт и логистика, туризм, частная медицина, горнорудная промышленность, обрабатывающая промышленность).

В целом всю экономику Дальнего Востока можно разделить на три больших сектора по степени травматичности от пандемии (рuс. 4). Самый большой сектор (почти 2/3 всей экономики) образуют виды экономической деятельности, потерявшие и до сих пор теряющие доходы и снизившие оборот в результате снижения спроса. 13\% экономики составили те производства и сектора, которые несут и несли потери и даже ушли с рынка в результате весеннего локдауна и тех ограничений, которые вводятся с октября, в том числе и на территории Дальнего Востока. Ну и примерно пятая часть экономики оказалась в выигрыше (частично медицина, частично образование, фармацевтическая промышленность, электроэнергетика, нефтеперерабатывающая промышленность, связь).

В целом экономические потери по ДФО можно оценить только приблизительно. В промышленности только за январь - август 2020 г, если сравнивать его с тем же периодом 2019 г., общее сокращение стоимости промышленной продукции составили, примерно 160 млрд руб., или 7,5\% совокупной стоимости промышленного выпуска по Дальнему Востоку. Индекс стоимости отгруженных товаров в этот период 2020 г. по сравнению с прошлым годом составил всего 93,4\% в добывающей и чуть больше 90\% в обрабатывающей промышленности. При этом удельные затраты в ряде случаев не уменьшались, о чем свидетельствует потребление электроэнергии - несмотря на все ограничения, потребление электроэнергии даже увеличилось более чем на $3 \%$ по сравнению с аналогичным периодом 2019 г. (45,2 против 43,7 гигаватт/часов соответственно). Сказалось то, что есть виды электропотребления, которые просто нельзя отключить, даже если остановлено производство. Кроме этого существенно увеличилось потребление электроэнергии домашними хозяйствами в связи с самоизоляцией. 


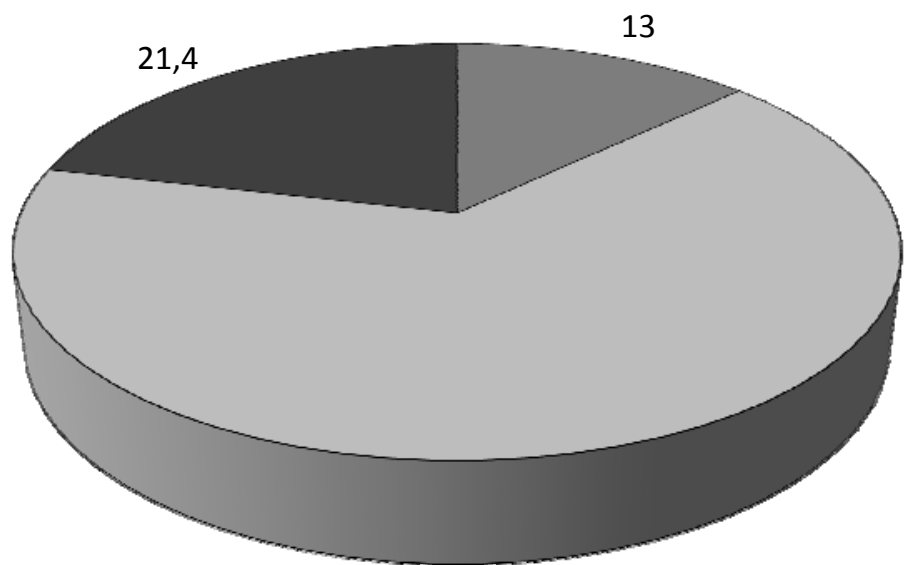

65,6

Виды деятельности, пострадавшие из-за весенного локдауна

$\square$ Виды деятельности, пострадавшие из-за снижения совокупного спроса

Виды деятельностпи, выигравшие или оставшиеся нейтральными

Puc. 4. Структура видов экономической деятельности по степени потерь от пандемии, \%

Fig. 4. Structure of economic activity types by share of loss from the pandemic, \%

Существенные потери понес Дальний Восток не только в промышленном производстве, но и в целом по экономике. В 2019 г. оценочный темп роста ВРП на Дальнем Востоке составлял 103\% в год (Прокапало и др., 2020, c. 146). Если учесть снижение темпа в отраслях, которые пострадали из-за локдауна в апреле - июле и страдают сейчас, а также в отраслях, которые пострадали от сокращения внутреннего и внешнего спроса, то общий темп за 2020 г. ожидается, по предварительной оценке, на уровне 95\%, а, соответственно, по стоимости общие потери ВРП могут достичь 300 млрд руб. В масштабах всего федерального округа примерно это соответствует потере доходов региональных бюджетов на уровне до 50 млрд руб., или 7-9\% совокупных доходов всех бюджетов Дальневосточного федерального округа, как они планировались на 2020 г. еще до пандемии в январе текущего года. Если в начале года, например, суммарное положительное сальдо бюджетов федерального округа оценивалось в 65 млрд руб., то на начало ноября эта оценка сократилась до 15-20 млрд руб. Но эта сумма учитывает положительное сальдо бюджета Сахалинской области, которое по плану этого года составляло более 43 млрд руб. Если исключить из расчета Сахалинскую область, которая находится в несколько особом финансовом положении благодаря нефтегазовым ресурсам и роялти, которое получает от этих ресурсов, то совокупное сальдо всех остальных дальневосточных субъектов РФ станет отрицательным по итогам 11 месяцев и составит -24-29 млрд руб. 
Эти потери можно возместить только за счет федеральных межбюджетных трансфертов.

Неоднозначно оценивается ситуация на рынке труда Дальневосточного федерального округа. Общая квота по иностранной рабочей силе в начале 2020 г., установленная на основании постановления правительства (Об определении..., 2019), составляла 41,4 тыс. чел. В основном должны были привлекаться рабочие для строительства, сельского хозяйства, добычи полезных ископаемых, транспорта, торговли, услуг, при этом примерно 20\% этой квоты приходилось для рабочих из Китая и других так называемых визовых работников, то есть неиностранных рабочих из стран СНГ, которые могут приезжать без виз. То, что границы закрыты, практически отрезало китайскую рабочую силу от рынка Дальнего Востока. Но и рабочие из стран СНГ оказались отрезаны от рынка труда в России из-за закрытия границ. Отсутствие китайских рабочих не оказало сильного воздействия на сельское хозяйство Дальнего Востока, и не только на сельское хозяйство, а вообще на экономику региона, потому что и до начала пандемии китайцы минимизировали свое трудовое участие на Дальнем Востоке, поскольку старались избегать всевозможных ограничений, которые начали в последнее время на них накладывать. Даже в Амурской области, казалось бы, следовало ожидать большого ущерба от отсутствия китайских рабочих в сельском хозяйстве, но этого не произошло, так как даже в этой области китайские рабочие в основном работают не в сельском хозяйстве, а закупают сельскохозяйственную продукцию Амурской области, поэтому закрытие границ в этом смысле оказало некоторое влияние. Такая же ситуация и в Приморском крае. Пожалуй, некоторым исключением является Еврейская автономная область, в которой сложилась критическая ситуация, поскольку там китайский бизнес почти на $80 \%$ обеспечивает обработку земель.

В строительстве основные, наиболее крупные проекты, такие как газохимический комплекс в Амурской области, космодром, судостроительные верфи, реконструкция аэропортов и автомобильных дорог, строительство мостов - все эти проекты практически не пострадали от отсутствия иностранной рабочей силы, так как основная часть рабочих из-за границы - это квалифицированные трудовые ресурсы на этих объектах, и им по-прежнему, даже в условиях пандемии, выделялись специальные квоты, выдавались специальные рабочие визы для завоза из-за рубежа по специальным разрешениям, а также квалифицированные рабочие продолжали прибывать вахтовым методом из европейской части страны. Строительные фирмы из Китая, которые присутствовали на рынках больших городов Дальнего Востока, ушли на это время с рынка, так как не могли привлекать на это время своих рабочих, но это не оказало большого влияния, в силу того, что их 
операции не имели большого объема на строительном рынке, и они начали сворачиваться, чтобы избежать различного рода ограничений, уже давно.

Проблемы в области рыбной промышленности в течение года возникали и возникают в связи с ограниченной возможностью перемещения, но главным образом, не иностранной рабочей силы, а вообще рабочей силы по территории страны, в частности, из-за необходимости проведения двухнедельного карантина для прибывающих рабочих. Кстати, та же необходимость двухнедельного карантина приводит к дополнительным затратам для рыбоперерабатывающего и добывающего флота, так как суда тоже обязаны проходить двухнедельный карантин при возвращении, например, с лова или при наборе команды для выхода в лов. Общий вылов рыбы увеличивается, но реальной проблемой является снижение спроса на продукцию рыбопереработки по ряду позиций, в частности, из-за остановки ряда предприятий общественного питания и на Дальнем Востоке, и особенно в европейской части страны, из-за невозможности вывоза продукции в ряде случаев в сопредельные страны тоже.

В области внешней торговли Дальнего Востока после существенного спада по итогам первых пяти месяцев товарооборота с Китаем (сокращение составило примерно 12\%) ситуация начала выправляться, и к августу товарооборот увеличился по сравнению с таким же периодом прошлого года на 0,5\%. Конечно, в целом по итогам года ожидавшегося прироста товарооборота внешней торговли в размере 1,2 млрд долл. (отталкиваясь от объемов приростов в 2019 г.) достичь уже не удастся. Отклонение от ожидавшегося прироста составит порядка 0,5 млрд долл., что эквивалентно 15-18\% общих потерь оборота в промышленности за 2020 г. при пересчете по действующему курсу рубля.

Каковы перспективы восстановления экономики Дальнего Востока и дальнейшего развития в соответствии с недавно принятыми новыми документами? Сейчас об этом трудно говорить, можно предположить, что для выхода федерального округа хотя бы на траекторию развития 2017-2019 гг, то есть для восстановления темпа роста порядка 103\% в год, необходимо полностью снять все ограничения внутри страны и на зарубежных рынках, восстановить динамику инвестиций, характерную для того периода. Очевидно, что в первом полугодии 2021 г. это вряд ли возможно будет сделать. Но следует учитывать, что в соответствии с недавно принятой Национальной программой развития Дальнего Востока до 2035 г. предусматривается достижение темпов роста чуть ли не 106\% в год. По оценкам, для этого необходимо увеличить размер ежегодных инвестиций как минимум вдвое, то есть до 3-3,5 трлн руб. при ежегодном приросте порядка 4\%. Учитывая потери российской экономики в 2020 г., а также стойкое нежелание ис- 
пользовать ресурсы Фонда национального благосостояния для инвестиций в экономику, с которым борется часть правительства, но пока неясно, чем закончится эта борьба, подобные предположения вряд ли реалистичны в ближайшие 2-3 года.

\section{СПИСОК ЛИТЕРАТУРЫ}

Карта распространения коронавируса в России и мире. 2020. URL: https://yandex.ru/ web-maps/covid19?1l=102.800291\%2C53.914915\&z=2.6 (дата обращения: декабрь 2020).

Курс российского рубля / banki.ru. 2020. URL: https://www.banki.ru/products/currency/ $\mathrm{rub} /$ (дата обращения: декабрь 2020).

Курюкин A.H. COVID-19 как вызов экономике, социуму, политике // МИР (Модернизация. Инновации. Развитие). 2020. Т. 11. № 3. С. 250-265. https://doi. org/10.18184/2079-4665.2020.11.3.250-265

Минакир П.А. Экономика пандемии: российский путь // Пространственная экономика. 2020. T. 16. № 2. С. 7-18. https://dx.doi.org/10.14530/se.2020.2.007-018

Нефть Brent / InvestFunds. 2020. URL: https://investfunds.ru/indexes/624/ (дата обращения: декабрь 2020).

Об определении потребности в привлечении иностранных работников, прибывающих в Российскую Федерацию на основании визы, в том числе по приоритетным профессионально-квалификационным группам, и утверждении квот на 2020 год: постановление Правительства РФ от 03 декабря 2019 г. № 1579. URL: https:// na.buhgalteria.ru/document/n177516 (дата обращения: ноябрь 2020).

Прокапало О.М., Бардаль А.Б., Исаев А.Г., Мазитова М.Г., Суслов Д.В. Экономическая конъюнктура в Дальневосточном федеральном округе в 2019 г. // Пространственная экономика. 2020. № 2. C. 142-184. https://dx.doi.org/10.14530/se.2020.2.142-184

Статистика / Фонд национального благосостояния. 2020. URL: https:/minfin.gov.ru/ru/ perfomance/nationalwealthfund/statistics/?id_65=27068-obem_fonda_natsionalnogo_ blagosostoyaniya (дата обращения: ноябрь 2020 ).

Auzan A.A. The Economy under the Pandemic and Afterwards // Population and Economics. 2020. Vol. 4. Issue 2. Pp. 4-12. https://doi.org/10.3897/popecon.4.e53403

Grigoryev L.M. Global Social Drama of Pandemic and Recession // Population and Economics. 2020. Vol. 4. Issue 2. Pp. 18-25. https://doi.org/10.3897/popecon.4.e53325

\section{REFERENCES}

Auzan A.A. The Economy under the Pandemic and Afterwards. Population and Economic, 2020, vol. 4, issue 2, pp. 4-12. https://doi.org/10.3897/popecon.4.e53403

Brent Oil. InvestFunds, 2020. Available at: https://investfunds.ru/indexes/624/ (accessed December 2020). (In Russian).

Grigoryev L.M. Global Social Drama of Pandemic and Recession. Population and Economics, 2020, vol. 4, issue 2, pp. 18-25. https://doi.org/10.3897/popecon.4.e53325

Kuriukin A.N. COVID-19 as a Challenge to the Economics, Society and Politics. MIR (Modernizatsiya. Innovatsii. Razvitie) = MIR (Modernization. Innovation. Research), 2020, vol. 11, no. 3, pp. 250-265. https://doi.org/10.18184/2079-4665.2020.11.3.250265 (In Russian). 
Map of the Spread of Coronavirus in Russia and the World. 2020. Available at: https:// yandex.ru/web-maps/covid19?1l=102.800291\%2C53.914915\&z=2.6 (accessed December 2020). (In Russian).

Minakir P.A. Pandemic Economy: The Russian Way. Prostranstvennaya Ekonomika = Spatial Economics, 2020, vol. 16, no. 2, pp. 7-18. https://dx.doi.org/10.14530/ se.2020.2.007-018 (In Russian).

On Determining the Need to Attract Foreign Workers, Arriving in the Russian Federation Based on a Visa, Including for Priority Professional Qualification Groups, and Approving Quotas for 2020: Decree of the Government of the Russian Federation No. 1579 of December 03, 2019. Available at: https://na.buhgalteria.ru/document/ n177516 (accessed November 2020). (In Russian).

Prokapalo M.N., Bardal A.B., Isaev A.G., Mazitova M.G., Suslov D.V. Economic Situation in the Far Eastern Federal District in 2019. Prostranstvennaya Ekonomika = Spatial Economics, 2020, no. 2, pp. 142-184. https://dx.doi.org/10.14530/se.2020.2.142-184 (In Russian).

Russian Ruble Exchange Rate. banki.ru, 2020. Available at: https://www.banki.ru/products/ currency/rub/ (accessed December 2020). (In Russian).

Statistics. National Welfare Fund, 2020. Available at: https://minfin.gov.ru/ru/perfomance/ nationalwealthfund/statistics/?id_65=27068-obem_fonda_natsionalnogo_ blagosostoyaniya (accessed November 2020 ). (In Russian).

Поступила в редакцию / Submitted: 30.11.2020

Принята к публикации / Revised: 07.12.2020

Опубликована online / Published online: 25.12.2020 